\title{
CONSIDERATIONS ON POPULATION ECOLOGY OF RED-BACKED SHRIKE (LANIUS COLLURIO LINNAEUS, 1758) AND WOODCHAT SHRIKE (LANIUS SENATOR LINNAEUS, 1758) WITHIN BIRD COMMUNITIES IN AN AREA OF WESTERN ISTRIA
}

\author{
Roberto Guglielmi ${ }^{1} \&$ Miro TASso $^{2}$ \\ ${ }^{1}$ Via Ereditari n. 31 - 30027 San Donà di Piave, Venice - Italy (e-mail: robertorni@libero.it) \\ ${ }^{2}$ Via Porara n. 79 - 30035 Mirano, Venice - Italy (e-mail: mtass2002@libero.it)
}

Guglielmi, R., \& Tasso, M.: Considerations on population ecology of Red-backed shrike (Lanius collurio Linnaeus, 1758) and Woodchat shrike (Lanius senator Linnaeus, 1758) within bird communities in an area of Western Istria. Nat. Croat., Vol. 24, No. 1, 127-138, 2015, Zagreb.

In July and August 2013, in an area of Western Istria, research into the co-presence of the red-backed shrike (Lanius collurio) and the woodchat shrike (Lanius senator) was carried out among the bird communities within 17 parcels of land, delimited by the main vehicular roads. Among 60 shrike settlements, 6 sympatric settlements were found, in which the woodchat shrike is dominant over the red-backed shrike in large open areas, while the latter presents a higher colonizing capability. A comparison of the bird communities by means of the Bray-Curtis similarity coefficient indicated the existence of a cluster made up of central and northern parcels of land characterized by a better environmental quality, in which the highest diversity indexes were found.

Key words: Red-backed shrike, Woodchat shrike, Western Istria, Bray-Curtis index, diversity index, bird communities

Guglielmi, R. \& Tasso, M.: Razmatranja o ekologiji gniježđenja rusog svračka (Lanius collurio Linnaeus, 1758) i riđoglavog svračka (Lanius senator Linnaeus, 1758) u kontekstu ptičjih zajednica na području zapadne Istre. Nat. Croat., Vol. 24, No. 1, 127-138, 2015, Zagreb.

Tijekom mjeseci srpnja i kolovoza 2013. godine na području zapadne Istre vođeno je istraživanje o suživotu rusog svračka (Lanius collurio) i riđoglavog svračka (Lanius senator) u ptičjim zajednicama unutar 17 zemljišnih parcela omeđenih glavnim kolnim putevima. Na 60 staništa svračaka bilo je utvrđeno 6 simpatričkih staništa, s dominiranjem rusog svračka nad riđoglavim svračkom u prostranim otvorenim predjelima, dok riđoglavi svračak pokazuje bolje sposobnosti naseljavanja. Usporedba ptičjih zajednica, putem Bray-Curtisovog koeficijenta sličnosti, omogućila je utvrđivanje postojanja klastera, kojeg čine središnje sjeverne parcele čije je obilježje veća kvaliteta staništa i gdje su registrirane veće vrijednosti indeksa raznolikosti.

Ključne riječi: rusi svračak, riđoglavi svračak, zapadna Istra, Bray-Curtisov indeks, indeks raznolikosti, ptičje zajednice

\section{INTRODUCTION}

The red-backed shrike and the woodchat shrike are two species considered respectively as SPEC 3 and SPEC 2 in Europe (BIRDLifE INTERNATIONAL, 2004), that is, moderately declining species. The red-backed shrike's decline seems to be largely due to loss and deterioration of habitat (HeAt, 1994; Fornasari et al., 1997; BirdLife InTERnational, 2004; 
Yosef, 1994). Intensive agriculture and the disappearance of traditional agricultural landscapes (BrAmbilla et al., 2007) are considered to be among the main causes of loss of suitable habitats. In Croatia, between 1990 and 2000 the two species underwent a strong reduction in population ranging from $50 \%$ and $79 \%$ for the red-backed shrike and from $0 \%$ and $19 \%$ for the woodchat shrike (BirdLife International, 2004). According to the Red data book of birds of Croatia, the breeding populations of the two species in Croatia are stable (Lc). The red-backed shrike is an important Natura 2000 species (Tutrš et al., 2013)

Because of this great decline, we decided to study the actual consistency and distribution of these two species of shrikes in an area of western Istria, focusing on the problem of their coexistence, within the respective different bird communities they belonged to.

The ecological factors which might explain both sympatric and competitive exclusion conditions between the two same-breed species were taken into account according to GAusE's theory (1934).

The present research provides the results of the analysis and might act as an instrument for the future planning of any active territory management to safeguard the species.

\section{Study area}

The research was carried out within the Poreč region $\left(45^{\circ} 13^{\prime} \mathrm{N}-13^{\circ} 39^{\prime} \mathrm{E}\right)$ (Fig. 1), in Western Istria, near the coast, along an area about $20 \mathrm{~km}$ long- from the mouth of the

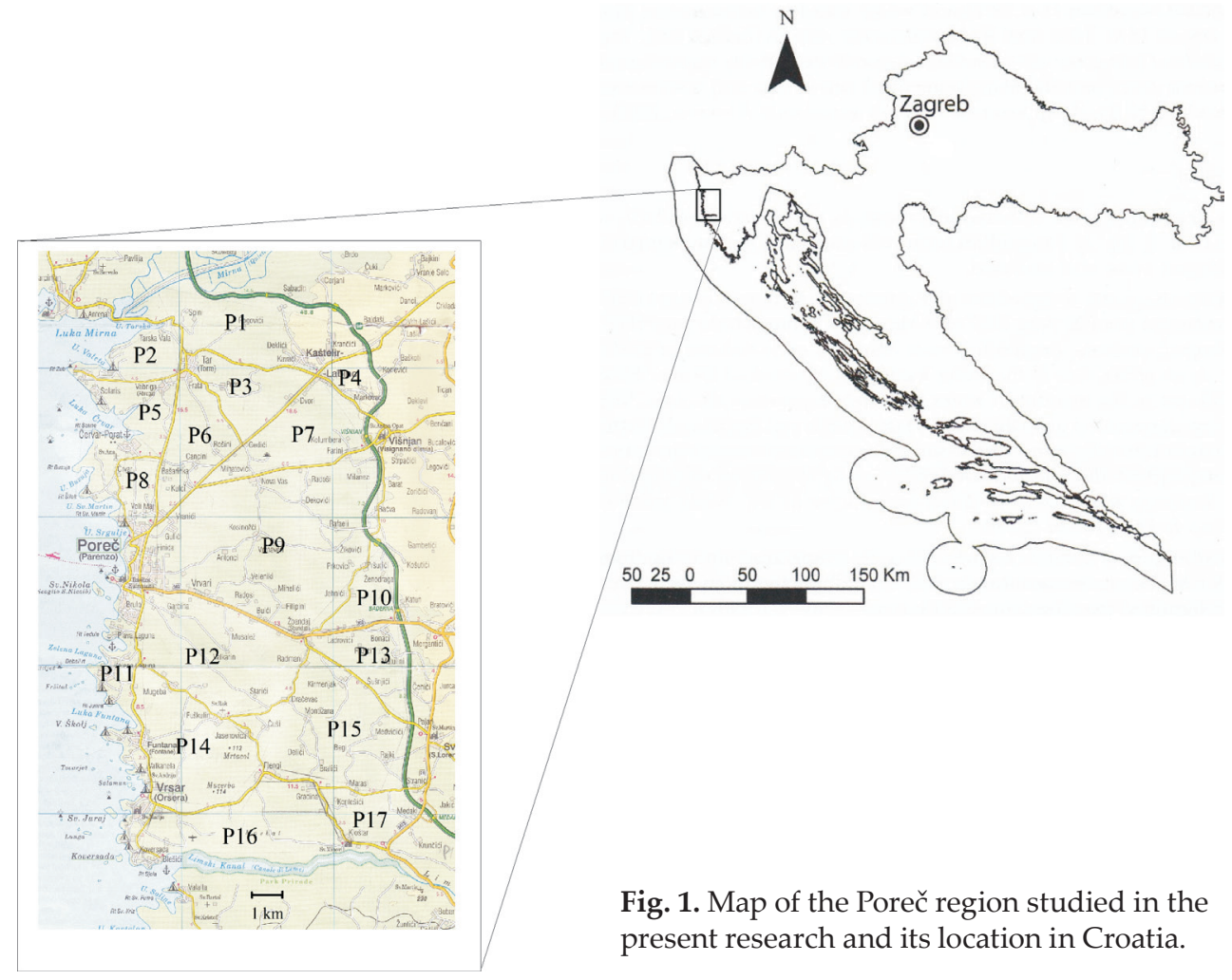


Tab. 1. Topographical-environmental parameters, ecological indexes, demographic and reproductive factors about red-backed shrike (Lanius collurio) and woodchat shrike (Lanius senator) populations per single parcel of land.

\begin{tabular}{|c|c|c|c|c|c|c|c|c|c|c|c|c|}
\hline \multirow[b]{2}{*}{ 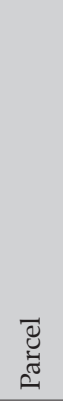 } & \multirow[b]{2}{*}{ 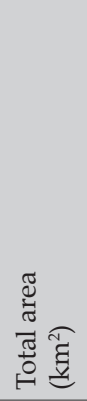 } & \multirow[b]{2}{*}{ 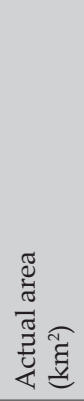 } & \multirow[b]{2}{*}{ 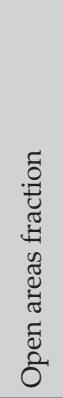 } & \multirow[b]{2}{*}{ 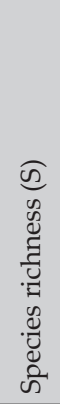 } & \multirow{2}{*}{ 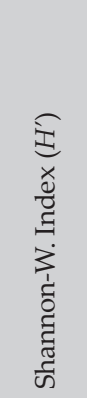 } & \multirow[b]{2}{*}{ 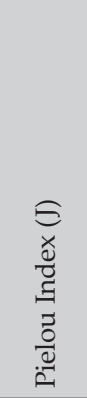 } & \multicolumn{2}{|c|}{ 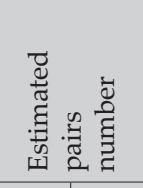 } & \multicolumn{2}{|c|}{ 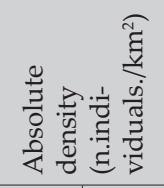 } & \multicolumn{2}{|c|}{ 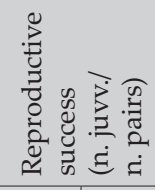 } \\
\hline & & & & & & & 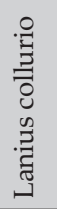 & 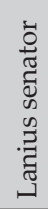 & 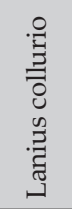 & 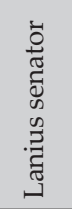 & 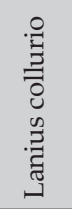 & 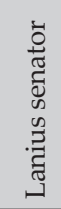 \\
\hline P1 & 12.54 & 7.52 & 0.6 & 27 & 1.280 & 0.892 & 4 & 6 & 1.86 & 1.6 & 2.25 & 0.17 \\
\hline P2 & 3.42 & 2.74 & 0.8 & 10 & 0.938 & 0.938 & - & - & - & - & - & - \\
\hline P3 & 7.05 & 3.53 & 0.5 & 23 & 1.230 & 0.905 & 7 & 4 & 3.12 & 3.40 & 0.57 & 1.5 \\
\hline P4 & 2.13 & 1.70 & 0.8 & 7 & 0.767 & 0.908 & 1 & - & 1.18 & - & 1.00 & - \\
\hline P5 & 10.28 & 6.17 & 0.6 & 27 & 1.280 & 0.891 & 4 & 1 & 0.97 & 0.16 & 0.5 & - \\
\hline P6 & 8.40 & 5.89 & 0.7 & 26 & 1.250 & 0.881 & 2 & 8 & 1.02 & 4.07 & 1.5 & 1.38 \\
\hline P7 & 7.79 & 6.23 & 0.8 & 22 & 1.060 & 0.792 & 6 & 4 & 3.85 & 2.89 & 2.17 & 2.5 \\
\hline $\mathrm{P} 8$ & 2.86 & 1.43 & 0.5 & 13 & 1.010 & 0.906 & 2 & 1 & 2.65 & 4.19 & - & 4.00 \\
\hline P9 & 36.64 & 7.33 & 0.2 & 23 & 1.160 & 0.849 & 11 & - & 4.37 & - & 1.45 & - \\
\hline P10 & 4.55 & 2.73 & 0.6 & 9 & 0.803 & 0.842 & 1 & - & 0.73 & - & 2.00 & - \\
\hline P11 & 7.0 & 1.40 & 0.2 & 14 & 1.030 & 0.897 & 2 & - & 5.00 & - & 2.00 & - \\
\hline $\mathrm{P} 12$ & 15.84 & 9.50 & 0.6 & 18 & 1.000 & 0.800 & 6 & 1 & 2.00 & 0.21 & 2.17 & - \\
\hline $\mathrm{P} 13$ & 6.37 & 0.64 & 0.1 & 8 & 0.810 & 0.897 & - & - & - & - & - & - \\
\hline $\mathrm{P} 14$ & 13.25 & 9.28 & 0.7 & 17 & 1.050 & 0.854 & 3 & - & 0.97 & - & 1.67 & - \\
\hline $\mathrm{P} 15$ & 15.19 & 4.56 & 0.3 & 21 & 1.100 & 0.833 & 5 & 3 & 3.28 & 2.19 & 2.6 & 1.33 \\
\hline P16 & 11.88 & 2.38 & 0.2 & 11 & 0.887 & 0.852 & 1 & - & 0.84 & - & 2.00 & - \\
\hline P17 & 4.59 & 0.46 & 0.1 & 6 & 0.709 & 0.911 & 1 & - & 4.34 & - & 2.00 & - \\
\hline
\end{tabular}

river Mirna to the North and Limski canal to the South - and about $10 \mathrm{~km}$ wide, from the coast inland. The Eastern limit of the study area was the motorway crossing the Istria peninsula, called the " $Y$ " after its shape. The region has a Mediterranean climate, the average temperature of the hottest month (August) being $24^{\circ} \mathrm{C}$ ) and the lowest temperature of the coldest month (January) $5^{\circ} \mathrm{C}$. Yearly rainfall reaches $920 \mathrm{~mm}$ and is equally distributed through the year. The principal winds are the Bora, blowing from the North, mainly in winter; the Scirocco, blowing from the South in summer. The prevailing habitat is characterized by a mosaic of vineyards and farmed lands, woods of deciduous oaks and pines as well as open areas with huckleberry and Mediterranean scrub. The study area was $73.49 \mathrm{~km}$ large and was subdivided into 17 parcels, delimited by the main vehicular roads (Fig. 1). The total surface area was large, approximately $21 \mathrm{~km}^{2}$. Such a 
subdivision was adopted since red-backed shrike couples tend to nest a few meters from roads, using them to delimit territories (Morelli \& PANdolfi, 2011; Morelli, 2012), while roads seem to have a negative effect on woodchat shrikes as regards relative abundance (Peris \& Pescador, 2004). Parcel area ranged from a minimum of 2.13 square kilometers to a maximum of 36.654 square kilometers, with an average of 9.58 square kilometers (Tab. 1) .

\section{MATERIALS AND METHODS}

The on-the-spot study was carried out from early July until the middle of August 2013, for a total of 38-day sightings and 190-hour observations. Such a time window was chosen to track efficiently whole family groups of shrikes - made up of parents and young (the latter were easily identified thanks to the characteristic call - because species of the Lanius genus have a reproductive calendar shifted more towards late summer than other passerines (TRYJANOWSKI et al., 2003). While gathering shrike data, we also gathered data about the number of individuals of all the other bird species; the goal was to consider the sympatry and competitive exclusion factors within bird communities belonging to the shrikes. The relative frequencies of all the bird species resulting from the analysis may not be considered really representative estimates of the fractions of individuals of the different nesting species, precisely because the time window adopted for data gathering was moved towards high summer, that is the period when, for a lot of species, reproduction is over and their pre-migratory stage or - as far as the young are concerned - their post fledgling flight dispersion, is about to start or has already started. Despite these limits, we preferred to include in the survey all species so as to provide a better ecological interpretation of the data about shrikes. In every parcel of land, spotting was carried out only in open areas representing habitats potentially able to host reproductive couples of shrikes, to the exclusion of all the thickly wooded areas, as well as towns, considering both of them unsuitable for the studied species.

The bird data collection was carried out using the line transect technique (JARvineN \& VAISANEN, 1977). Bird species recognition was obtained by sight, or by listening to the territorial songs of males and/or the species-specific calls of both sexes. Observations were carried out by means of 10x36 binoculars and 20-60 x 80 telescope. Data gathered through transects were stored within each parcel of land and processed to obtain the different parameter values. First of all came species richness (S): the sum of all species recorded, i.e., the Shannon-Weaver index, which derives from information theory (SHANNON \& WEAVER, 1949). It is an index of diversity, based on the proportional abundances of species, and it is defined by:

$$
H^{\prime}=-\sum p_{i} \log p_{i^{\prime}}
$$

where $p_{i}$ is the frequency of the bird species $i$. In particular, $H^{\prime}=0$ if and only if all the $p_{i}$ but one are zero, this one having the value of unity, instead the maximum value of $H^{\prime}$ is given by $n$ hypothetical situation where all bird species are equally abundant, i.e., when all the $p_{i}$ are equal (SHANNON \& WEAver, 1949). We computed the $H^{\prime}$ value in each parcel of land for all bird species. Another ecological parameter is the equitability index, and it is defined by:

$$
J=H^{\prime} / \ln S,
$$

where $H^{\prime}$ is the index of diversity, and $S$ is the number of species in a community (LLOYD \& Ghelardi, 1964; Pielou, 1966), i.e., a parcel of land. Other parameters are: the relative 
frequency of single species, that is, the number of observations of the $i$ th bird species compared to the total; absolute density, represented by the number of individuals/real study area within the parcel of land. Absolute densities were taken into account only for shrikes while the other bird species were excluded. The number of shrike couples, of both species, for a single settling, was also considered; by single setting we mean each nucleus of shrike couples which might be made up also by a single couple. The $\left(\chi^{2}\right)$ test was used to evaluate the association between settlement dimension and its frequency. Mann-Whitney's U-test was used to evaluate the possible effect of the competition between the two shrike species onto absolute density and reproductive success. Shrike absolute densities were correlated with the fraction of open areas compared to the total surface, for each parcel of land, by means of Spearman's coefficient $\left(r_{s}\right)$. The fraction of open areas for each parcel of land represented by the ratio between the open-zone area and the total area - varying from 0 (whole woody area) to 1 (wholly open-areas) - was obtained through the observation of the relative proportion of each type of vegetation covering each parcel of land through Google Maps.

The numbers relative to all the bird species collected in the 17 parcels of land of this region allowed us to obtain a matrix with the number of individuals corresponding to each bird species in each parcel of land. This matrix was used for determining, between each pair of parcels of land, the Bray-Curtis similarity coefficient (BRAY \& CURTIS, 1957), where the similarity $S_{j k}$ between the $j$ th and $k$ th parcels of land is given by the formula:

$$
S_{j k}=100\left\{1-\sum_{i=1}^{p}\left|y_{i j}-y_{i k}\right| / \sum_{i=1}^{p}\left(y_{i j}+y_{i k}\right)\right\}
$$

where $p$ is the number of bird species, $y_{i j}$ represents the number of individuals for the $i$ th bird species in the $j$ th parcel of land, whereas $y_{i k}$ represents the number of individuals for the $i$ th bird species in the $k$ th parcel of land; $\mid$... is the absolute value of the difference for the aforesaid numbers of individuals. The computation of this coefficient is very simple and it permits the verification of two extreme values (CLARKE \& WARWICK, 1994): $S=0$ if the two parcels of land have no bird species in common, $S=100$ if the two communities are identical.

We used cluster analysis for grouping single parcels of land; thit was based on the Bray-Curtis similarity index, so that the parcels of land within a group are more similar to each other than the parcels of land in different groups. Of course, two bird communities may present different structures, even if they share the same species, if the distribution of the number of individuals is substantially different in the different groups. The method is a form of hierarchical agglomerative clustering, which takes a similarity matrix as its starting point and successively fuses the samples into groups, after which the groups are gathered into larger clusters, starting with the highest mutual similarities, the similarity level at which groups are formed then being gradually lowered. The process ends with a single cluster containing all the samples. The results of hierarchical clustering, using the group-average linking of Bray-Curtis similarities, is represented by a dendrogram (CLARKE \& WARWICK, 1994). Afterwards, we applied the non-metric multidimensional scaling (nmMDS) to the matrix of similarity (CLARKE \& WARWICK, 1994). This process shows a topological representation that graphically emphasizes the links among the bird communities considered inf this research; easier to interpret, it is formed in order to respect the existing degree of similarity between one community and all the others. This representation is carried out so as to preserve the rank order of similarities as Euclidean distances in a two-dimensional diagram; this transformation of similarity 
in distances is carried out by means of a non-parametric regression, whose success is measured by a "stress coefficient", which reflects the degree of data dispersion around the regression line (CLARKE \& WARWICK, 1994). In short, the topological representation is the most suitable for clear visualization of the similarity among the parcels of land examined: the nearer the points that represent them are, the more similar they are with regard to the respective structures of the bird species.

\section{RESULTS}

On the whole, 156 red-backed shrikes and 85 woodchat shrikes were counted; with 56 and 28 couples estimated respectively and with a nesting density equal to 0.76 pair/ $\mathrm{km}^{2}$ for the red-backed shrike, and 0.38 pair $/ \mathrm{km}^{2}$ for the woodchat shrike. The reproductive success estimated is equal to 1.62 juv./pairs with the red-backed shrike, and 1.53 with the woodchat shrike. Of the total amount of parcels of land, the red-backed shrike occupies 15 (88.24\%) parcels; while the woodchat shrike occupies 8 (47.06\%) of them; there were 8 parcels presenting both species (47.06\%). In all the parcels where the woodchat shrike is present, the red-backed shrike is also present, but the converse does not hold true. The total number of settlements was 60,42 (70\%) of which made up of redbacked shrike couples only; 12 (20\%) of woodchat shrikes only; while $6(10 \%)$ present sympatric settlements. (Fig. 2). Forty two red-backed shrike settlements out of 48, 6 of which are sympatric, are made up of one couple only, with a highly significant statistical association $\left(\chi^{2}=63.5 ; \mathrm{P}<0.01\right)$, while 10 woodchat shrike settlements out of 18,6 of which are sympatrics, are made up of one pair only, with a statistically significant association $\left(\chi^{2}=8.91 ; \mathrm{P}<0.05\right)$ (Fig. 3). With respect to the red-backed shrike we found no statistically significant differences between medians, neither for absolute densities $(U=26.5$; $P>0.05$, Mann-Whitney $U$-Test $)$, nor for reproductive success $(U=14.5 ; P>0.05$, MannWhitney $U$-Test), between parcels in which this shrike is the only Lanius species present, and those in which both shrike species are present.

A negative correlation, on the edge of statistical relevance, between red-backed shrike absolute density and the fraction of open zones per parcels of land $\left(r_{s}=-0.42 ; \mathrm{P}=0.05\right)$ was found; while no statistically significant correlation between such variables was found with the woodchat shrike. However, we must remember that the parcels representing a fraction of open zones lower than $30 \%$ of the total surface do not host this species. In Tab. 1, the topographic-environmental, demographic and reproductive parameters with shrike populations within each single parcel of land and the values of diversity indexes are summarized. In Tab. 2, the relative frequencies regarding bird species per parcel of land, are summarised.

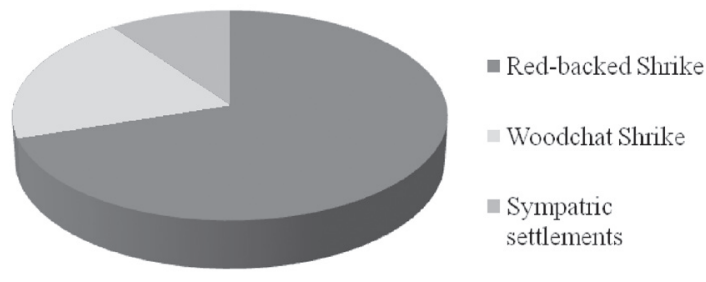

Fig. 2. Percentage distribution of the composition of shrike settlements. 


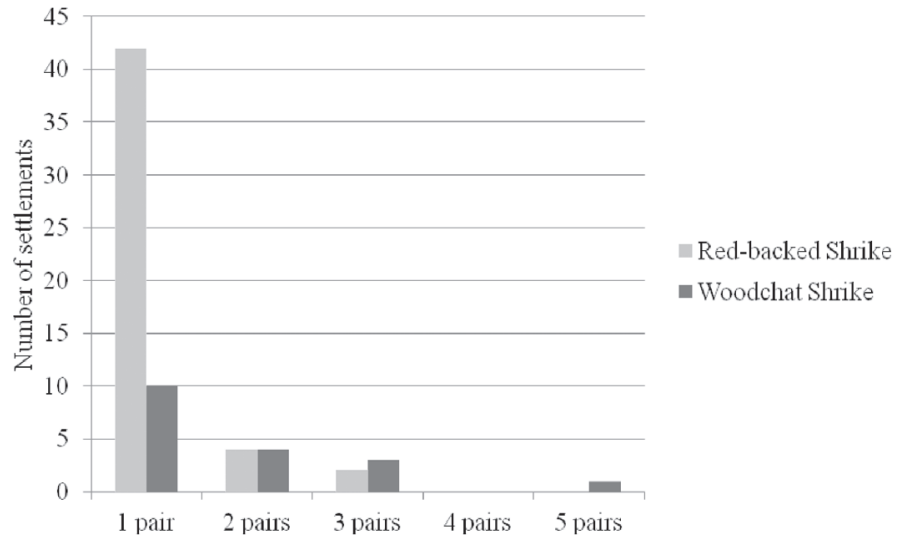

Fig. 3. Distribution of red-backed shrike (Lanius collurio) and woodchat shrike (Lanius senator) settlement numbers in connection with reproductive pairs number per settlement.

The topological representation describes on two dimensions the mutual relationships among the 17 bird communities analyzed, thus showing their similarity (Fig. 4). The resulting stress coefficient (0.188) enables us to state that the overall picture is adequately useful for interpretation (CLARKE \& WARWICK, 1994). Such an interpretation shows a cluster coinciding with the central and northern parcels, some of which are of high extension and are characterized by open zones (P1, P3, P5, P6, P7, P9, P11, P12, P14), differently from the remaining parcels, which are nearly all small and peripheral ones, mostly set on the graph margins (P2, P4, P8, P10, P13, P15, P16, P17). The P1, P3, P5, P6, $\mathrm{P} 7$ and $\mathrm{P} 9$ parcels of land belong to the topological representation cluster, where the

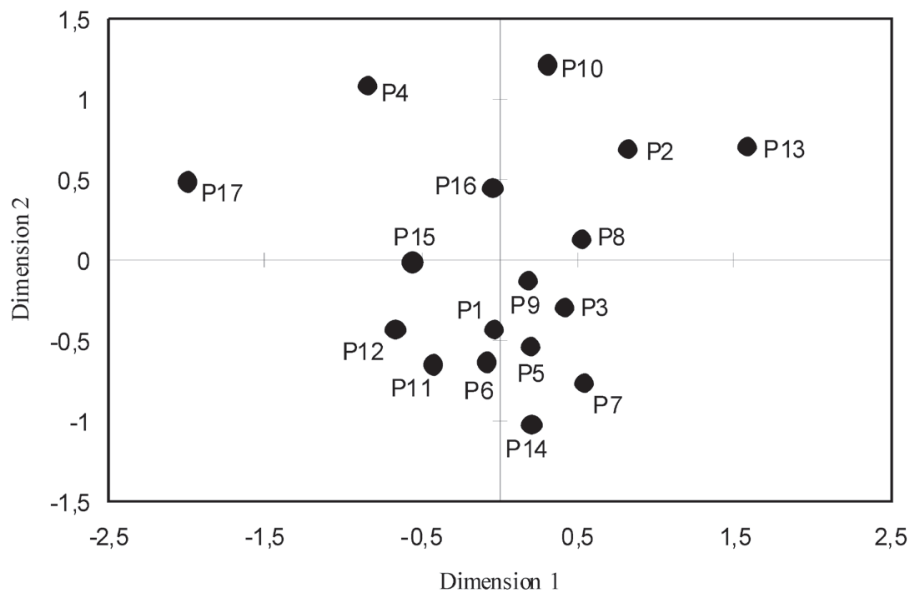

Fig. 4. Topological representation of similarity relations among the 17 bird communities examined (Stress=0.188). Each parcel of land is marked with an abbreviation whose geographical location is shown in Fig. 1. 
Tab. 2. Bird species found within the studied habitats, with relative frequencies $\left(p_{i}\right)$, per parcel of land. Dominant species $\left(p_{i}>0.05\right)$ in bold.

\begin{tabular}{|c|c|c|c|c|c|c|c|c|c|c|c|c|c|c|c|c|c|}
\hline Species & P1 & P2 & P3 & P4 & P5 & P6 & P7 & P8 & P9 & P10 & P11 & P12 & P13 & P14 & P15 & P16 & P17 \\
\hline Phasianus colchicus & 0.01 & - & 0.03 & - & - & 0.02 & - & - & 0.04 & - & - & - & - & 0.05 & 0.05 & - & - \\
\hline Circaetus gallicus & & - & - & - & - & - & - & 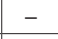 & .01 & - & 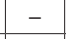 & - & - & - & - & - & - \\
\hline Buteo buteo & & - & 0.04 & & 0.01 & 0.01 & - & 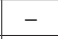 & 0.01 & - & - & 0.02 & - & 0.02 & - & - & 0.08 \\
\hline Pernis a & - & - & .01 & & - & - & 0.01 & _- & - & - & - & - & - & - & - & - & - \\
\hline Accipiter nisus & - & - & - & - & - & 0.01 & - & - & - & - & - & 0.03 & - & - & 0.01 & - & 0.08 \\
\hline Falco tinnunculu & 0.01 & - & - & - & - & - & - & - & - & - & - & - & - & - & - & - & - \\
\hline Tring & & - & - & - & - & - & - & - & - & - & - & - & - & - & - & - & - \\
\hline Columt & - & - & 0.03 & 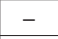 & - & 0.04 & - & - & - & - & - & - & - & - & - & - & - \\
\hline Streptop & - & - & - & - & 0.06 & 0.01 & 0.01 & - & - & - & - & - & - & - & - & - & - \\
\hline Streptopelia turtur & 0.04 & - & 0.04 & - & 0.02 & 0.04 & 12 & 0.03 & 0.03 & - & 0.03 & - & 0.14 & 0.07 & - & - & - \\
\hline Upupa e् & & - & & - & - & - & & - & 0.02 & 0.05 & - & 0.02 & 0.07 & - & 0.01 & - & - \\
\hline & & & & - & 0.01 & 0.03 & & - & 0.01 & 0.05 & - & - & - & - & .01 & - & - \\
\hline Dendro & - & 0.05 & 0.01 & 0.07 & .01 & 0.01 & - & 0.03 & 0.02 & - & - & - & - & - & 0.01 & 0.03 & - \\
\hline Jynx torquilla & - & - & - & - & 0.01 & 0.03 & 0.01 & - & - & - & 0.03 & - & - & 0.02 & - & - & - \\
\hline Lullula arborea & - & 0.10 & 0.03 & 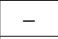 & - & - & & 0.03 & 0.05 & - & - & - & - & - & - & - & - \\
\hline & - & - & - & 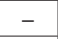 & - & - & & - & - & - & - & - & - & - & - & - & - \\
\hline & 02 & 0.05 & 0.07 & - & 0.04 & 0.03 & & 0.12 & 0.05 & - & - & 0.02 & 0.07 & 0.02 & - & 0.03 & - \\
\hline Lusci & 0.02 & - & - & - & 0.01 & - & & & 0.02 & 0.05 & - & - & - & - & - & - & - \\
\hline Oenanthe oenanthe & - & - & - & - & - & - & - & - & - & - & - & 0.02 & - & - & 0.01 & - & 0.08 \\
\hline & - & - & - & 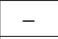 & - & - & - & - & - & - & - & 02 & - & - & 0.05 & - & - \\
\hline & - & - & - & 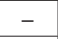 & - & - & - & - & - & - & - & - & 0.07 & 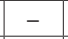 & - & - & - \\
\hline & - & - & & - & - & & & & - & - & & & - & & - & - & - \\
\hline Turdus & 0.03 & 0.16 & 0.08 & 0.33 & 0.10 & 0.06 & 0.02 & 0.06 & 0.09 & - & 0.07 & 0.07 & 0.07 & 0.04 & 0.10 & 0.15 & 0.25 \\
\hline Sylv & - & & - & - & - & - & - & - & - & - & - & - & - & - & 0.01 & - & - \\
\hline Sylvi & 0.02 & & & - & 01 & & - & - & 0.01 & - & 0.03 & & - & - & - & - & - \\
\hline & - & - & - & - & & & - & & & - & - & & & & - & - & - \\
\hline Sylvia c & & - & 0.01 & & - & - & - & & - & - & - & & - & - & 0.01 & 0.03 & - \\
\hline Hipp & 0. & - & - & & - & 0.02 & - & & - & 0.05 & - & 0.02 & - & 0.02 & - & - & - \\
\hline Phyllos & - & - & - & - & - & - & - & - & - & - & - & - & - & - & 0.01 & - & - \\
\hline & & - & & & & - & & & & - & & & - & & & - & - \\
\hline Parus $m$ & 0.02 & - & - & 0.07 & 03 & 0.04 & & - & \begin{tabular}{|l|}
0.02 \\
\end{tabular} & - & 0.07 & & - & 0.02 & 0.01 & 0.03 & - \\
\hline Cyanis & - & - & - & - & 0.01 & - & - & - & - & - & - & - & - & - & - & - & - \\
\hline Aegithalos caudatus & - & - & - & - & - & 0.07 & - & & - & - & - & - & - & - & 0.01 & - & - \\
\hline & & - & & & & & & & & & & & - & & & 0.06 & 0.17 \\
\hline Lanius sen & & - & & - & & 0.21 & & & & - & - & & - & - & 0.12 & - & - \\
\hline Pica pica & & - & - & - & .02 & - & 0.02 & & 0.02 & - & - & - & - & - & - & .09 & - \\
\hline Garrulus gl & 0.01 & 0.16 & 0.05 & - & 0.09 & 0.11 & - & 0.06 & 0.09 & 0.05 & 0.03 & 0.15 & 0.14 & 0.02 & 0.10 & 0.33 & 0.33 \\
\hline & - & & - & - & & - & & - & - & - & - & & - & & - & - & - \\
\hline & & - & & & & - & & & & - & & & - & 0.20 & - & - & - \\
\hline Oriolus oriolus & & & 0.04 & 0.20 & .03 & 0.02 & & & 0.02 & 0.11 & & & 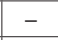 & & - & - & - \\
\hline Passer domesticus & 0.08 & 0.21 & 0.03 & - & 0.17 & 0.02 & 0.14 & 0.18 & 0.05 & 0.42 & 0.03 & 0.10 & 0.36 & 0.18 & 0.07 & 0.15 & - \\
\hline Passer montanus & & - & - & & - & - & & - & _ & - & - & - & - & - & - & - & - \\
\hline & & - & 0.03 & 0.07 & 0.02 & 0.02 & 0.01 & & 0.04 & - & & & - & - & 0.01 & 0.03 & - \\
\hline Carduelis carduelis & & - & - & - & 0.04 & 0.02 & & 0.12 & 0.04 & - & & 0.02 & - & & 0.02 & - & - \\
\hline Chloris chloris & 0.01 & - & - & - & 0.01 & 0.02 & 0.02 & - & - & - & 0.10 & - & - & 0.02 & - & - & - \\
\hline & - & - & - & & 0.02 & - & - & & - & - & - & - & - & 0.04 & - & - & - \\
\hline $\begin{array}{l}\text { Coccothraustes } \\
\text { coccothraustes }\end{array}$ & - & - & - & - & - & - & - & - & - & - & - & 0.02 & - & - & - & - & - \\
\hline Emberiza cirlus & & 0.05 & 0.07 & 0.13 & 0.03 & 0.07 & 0.03 & 0.03 & 0.10 & 0.11 & 0.03 & - & - & 0.05 & 0.16 & 0.09 & - \\
\hline Emberiza calandra & 0.02 & - & 0.01 & - & - & - & - & - & - & - & - & - & - & - & - & - & - \\
\hline
\end{tabular}


highest values of the species richness and Shannon-Weaver indexes were found. The highest absolute density values for the red-backed shrike were observed within parcels P7, P9, P11, and P17; while with the woodchat shrike, the highest absolute densities were observed within parcels P3, P6, P8. More specifically, the only settlement of woodchat shrike made up of 5 couples was found within parcel P6; this same parcel is the only one, among those in which the red-backed shrike is also present, within which the latter species does not dominate, i.e., without exceeding the relative frequency value of 0.05 . Among the 6 sympatric settlements, two are within parcel P15, and 1 is within parcel P8, neither of which are part of the cluster; while the other three, that is, parcels P1, P5 and $\mathrm{P} 7$, are within it.

\section{DISCUSSION}

The present research results confirm that the red-backed shrike and the woodchat shrike, being same-genus species, might have similar ecological needs, leading to habitat overlapping phenomena when in sympatric conditions. However, sympatry is limited to a small percentage of cases; the two species tend more to space separation than to coexistence. A sympatric condition with the two shrike species, or, more generally, their co-presence within the same parcel of land, does not seem to be accompanied either by a reduction of the reproductive success or an absolute density decrease in both species. In different Mediterranean habitats, where the two species are in sympatry, it has been found that the red-backed shrike has been affected negatively by competition with the woodchat shrike, in terms of decrease of nesting couple density (GUERRIERI \& $\mathrm{CA}_{\text {- }}$ STALDI, 2000). The sympatric settlements are mostly to be found within those parcels that, being part of the cluster observed in the topological representation, are characterized by a certain degree of ecological similarity. Such a similarity might reflect an elevated habitat suitability, depending on the maximum distance from both places of high anthropogenic disturbance, - set on the coast belt - and on the zones close to the motorway, where open habitats are degraded. It is also true that habitat or microhabitat overlap may not be very useful in indicating competition, as habitats may be "arenas" rather than the objects of competition (ScHOENER, 1974). Basically, the similarity among the central and northern parcels of land within the study area (Fig. 4), might be the result of the presence, in this portion of territory, of a higher quality habitat for various bird species living in open environments, which is evident from the diversity indexes found just in such parcels (Tab. 1). With reference to the distribution values of the two Lanius species, from north to south, there is a progressive rarefaction of the pairs present within each parcel of land, which is particularly true with the woodchat shrike (Tab. 1). Such a pattern might be associated with the presence of a wood cover gradient, since we pass from fractions of higher open areas on the northern sector, to lower values within several central and southern parcels (Tab 1), which might render southern habitats less suitable than northern ones since they are not as rich in open areas as the latter. However, the presence of a negative correlation, though a feeble one, between fraction of open areas per parcel of land and absolute density, might seem to contrast with the results mentioned above as to the red-backed shrike. Such a correlation might be interpreted as indirect evidence that the red-backed shrike is also successfully able to colonize limited open zones, even within a woody matrix, provided that such a matrix is dotted with portions of open habitats, not too far from one another. A confirmation is witnessed by the high number of red-backed shrike settlements made up of one single couple. The highest absolute densities with the red-backed shrike are to be found within the parcels 
which present low levels with the fraction of open areas, compared to the total surface; namely in P9, P11, P17. As to the woodchat shrike, the species seems to be bound to xeric environments, consequently it is absent in parcels having a fraction of open zones lower than $30 \%$ of the total surface, namely, P9, P11, P13, P16, P17. When compared to the same-genus species, the woodchat shrike seems to have a lower colonizing capability in open environments of limited width. Vice versa, when in a suitable environment, characterized by wide open areas with scattered bushes, the woodchat shrike forms settlements with a lot of pairs, as within parcel P6, competitively excluding from the settlement the red-backed shrike, which is also present in the parcel, without being dominant, that is, with a relative frequency not higher than 0.05. As to the coexistence of two species with similar ecological needs, coexistence requires that competing species exhibit a strict dominance hierarchy, i. e., superior competitors can displace inferior competitors from occupied patches, but an inferior competitor cannot displace a superior competitor (Hastings, 1980; NeE \& MAY, 1992; Tilman et al., 1994). Such a situation seems to have occurred within the examined region, between the two Lanius species, with the woodchat shrike taking over from the red-backed shrike. The latter, according to the competition-colonization theory (Levins \& Culver, 1971; Yu \& Wilson, 2001), being a competitively inferior species, manages to compensate for the negative effects of its rank, with a higher colonizing capability, favouring a partition of the occupied space occupied by the two species (AMARASEKARE, 2003).

\section{CONCLUSION}

Within the portion of Istria examined in the present research, there exist nesting populations of the red-backed shrike and the woodchat shrike which tend to spatial separation, with limited cases of sympatry, which do not seem to go along with relevant negative cases, either with one or the other species, relative to both their demographic and their reproductive parameters. The highest absolute density levels, considering overall data of both species, are to be found within mid-northern parcels of land, which seem to be characterized by a better environmental quality and lower anthropogenic disturbance. For the better preservation of these populations of species, which are diminishing in Europe, it is recommendable to preserve the mosaic of areas planted with vineyards, hedges, shrubberies, together with margins of deciduous oak woods, which represents the reproductive habitat for Laniidae in the Croatian area we have studied.

\section{ACKNOWLEDGEMENTS}

The authors would like to thank Dobrinka Kovačić for her Croatian translation of the abstract of this work. We also thank Dr. Maurizio Cesaro for the translation of the paper from Italian into English. 


\section{REFERENCES}

Amarasekare, P., 2003: Competitive coexistence in spatially structured environments: a synthesis. Ecology Letters, 6, 1109-1122.

BirdLife International, 2004: Birds in Europe: population estimates, trends and conservation status. Cambridge, UK: BirdLife International. (BirdLife Conservation Series No. 12).

Brambilla M., Rubolini D. \& Guidali F., 2007: Between land abandonment and agricultural intensification: habitat preference of Red-backed Shrikes Lanius collurio in low-intensity farming conditions. Bird Study, 54, 160-167.

BRAY, R.J. \& CURTIS, J.T., 1957: An ordination of the upland forest communities of Southern Wisconsin. Ecological Monographs, 27, 325-349.

Clarke, R.K. \& Warwick, R.M., 1994: Change in marine communities: an approach to statistical analysis and interpretation, Natural Environment Research Council-Plymouth Marine Laboratory, Plymouth (UK).

Fornasari, L., Kurlavicius P. \& Massa R., 1997: Lanius collurio Red-backed Shrike. In: Hagemeijer E. J. M. \& Blair M. J. (eds.). The EBCC Atlas of European Breeding Birds: their Distribution and Abundance. T e A. D. Poyser, London, UK, Pp. 660-661.

Gause, G. F., 1934: The Struggle for Existence. Williams and Wilkens, Baltimore.

Guerrieri, G. \& Castaldi A., 2000: Selezione di habitat e riproduzione dell'Averla capirossa, Lanius senator, nel Lazio - Italia centrale. Avocetta 24, 85-93.

Hastings A., 1980: Disturbance, coexistence, history and competition for space. Theory Population Biology, 18, 363-373.

Heath M. F., 1994: Red-backed Shrike Lanius collurio. In: Tucker G. M. \& Heath M. F. Birds in Europe. their conservation status. Cambridge, U.K.: BirdLife International (BirdLife Conservation Series n. 3). Pp. 410-411.

Jarvinen, O. \& Vaisanen, R. A., 1977: Line transect method: a standard for field work. Polish Ecological Studies, 3 (4), 11-15.

Levins, R. \& Culver, D., 1971: Regional coexistence of species and competition between rare species. Proceeding Natural Academy Science, USA, 68, 1246-48.

Lloyd, M. \& GHeLARDI, R. J., 1964: A table for calculating the equitability component of species diversità. Journal of Animal Ecology, 33, 217-225.

Morelli, F., 2012: Plasticity of habitat selection by Red-backed Shrikes (Lanius collurio) breeding in different landscapes. The Wilson Journal pf Ornithology, 124(1), 51-56. doi:10.1676/11-103.1

Morelli, F. \& Pandolfi, M., 2011: Breeding habitat and nesting site of the red-backed shrike Lanius collurio in farmland of the Marche region, Italy. Avocetta 35, 43-49.

NeE, S. \& MAY, R. M., 1992: Dynamics and metapopulations: habitat destruction and competitive coexistence. Journal Animal Ecology, 61, 37-40.

Peris, S. J. \& Pescador, M., 2004: Effects of traffic noise on passerine populations in Mediterranean wooded pastures. Applied Acoustics. 65, 357-366.

Pielou, E. C., 1966: The measurement of diversity in different types of biological collections. Journal of Theoretical Biology, 13, 131-144.

Shannon, C. E. \& Weave, R W., 1949: The mathematical theory of communication. University of Illinois Press, Urbana.

Shoener, T. W., 1974: Resource partitioning in ecological communities. Science, 185, 27-39.

Tilman, D., May R. M., Lehman C. L. \& Nowak M. A., 1994: Habitat destruction and the extinction debt. Nature (London), 371, 65-66.

Tryjanowski, P., Hromada, M., Antezak, M., GrzybeK, J., Kuźniak, S \& Lorek, G., 2003. Which method is most suitable for censusing breeding population of red-backed (Lanius collurio) and great grey ( $L$. excubitor) shrikes? Ornis Hungarica, 12-13, 223-228.

Tutiš, V., Kralj, J., Radović, D., Ćiković, D. \& Barišić S. (eds), 2013: Crvena knjiga ptica Hrvatske. MZOIP \& DZZP, Zagreb.

Yosef, R., 1994: Conservation commentary: evaluation of the global decline in the True Shrikes, family Lanidae. The Auk, 111, 228-233.

Yu, D. W. \& Wilson, H. B., 2001: The competition-colonization trade-off is dead; long live the competition-colonization trade-off. American Naturalist, 158, 49-63. 


\title{
SUMMARY
}

\section{Considerations on population ecology of Red-backed shrike (Lanius collurio Linnaeus, 1758) and Woodchat shrike (Lanius senator Linnaeus, 1758) within bird communities in an area of Western Istria}

\author{
R. Guglielmi \& M. Tasso
}

In July and August 2013, in an area of Western Istria, coinciding with the Poreč region, research was carried out to test the consistency and distribution of the nesting population of the red-backed shrike (Lanius collurio) and the woodchat shrike (Lanius senator), indicating the effects of the inter-specific competition between the two species.

At the same time, data on the amount of individuals of all the other species belonging to the same bird community were also gathered and elaborated to obtain two diversity indexes. The study area was subdivided into 17 parcels of land, delimited by the main vehicular roads, which were compared with the use of the Bray-Curtis similarity coefficient.

On the whole, 56 pairs of red-backed shrikes and 26 pairs of woodchat shrikes were found: the nesting shrike pairs were partitioned into 42 red-backed shrike settlements (colonies), 12 woodchat shrike settlements and 6 sympatric settlements.

The woodchat shrike occupied only those parcels with a fraction of open zones no lower than $30 \%$ of the total surface. In wider more extended areas, the woodchat shrike took over from the red-backed shrike, but the latter has a greater colonizing capability as far as new sites are concerned; in fact, $87.5 \%$ of the settlements of this species are made up of one pair. The statistical analysis has shown that there exists a negative correlation between the absolute density of the red-backed shrike and the fraction of open zones per parcel of land, thus showing the colonizing capability of the species in open areas of little width, within a woody matrix. As regards the effects of possible competition between the two species of shrikes, among the parcels of land where the red-backed shrike is the only Lanius species present, and those where both the red-backed shrike and the woodchat shrike are present, no significant statistical difference resulted between the median of the absolute density and the reproductive success, which might suggest a mild inter-specific competition. The ecological comparison based on similarity, indicated a cluster made up of Mid-North particles, which can be explained both with the high environmental quality within them, and with the maximum distance from the most anthropogenic and degraded sites. These factors are likely to explain the high values of the diversity indexes which are present in these particles, where an environmental mosaic is present and is characterized by vineyards, hedges, glades with scattered bushes and fringes of deciduous oak woods, which represent a reproductive habitat suitable to shrikes, and which must be preserved for the future. 